\title{
A Case Report of Benign Pancreatic Hyperenzymemia (Gullo's Syndrome)
}

\author{
Parth Mehta ${ }^{1,2}$, Anil Kumar Reddy Reddivari ${ }^{1}$ \\ 1. Internal Medicine, University of Illinois College of Medicine, Peoria, USA 2. Internal Medicine, Unity Point Health \\ Methodist Hospital, Peoria, USA
}

Corresponding author: Parth Mehta, drparthmehta@gmail.com

\begin{abstract}
Benign Pancreatic Hyperenzymemia or Gullo's Syndrome is a rare syndrome that has been identified relatively recently and is characterized by abnormally elevated serum pancreatic enzymes in the absence of any clinical or pathological evidence of pancreatic disease. It is usually discovered incidentally, occurs sporadically or as a familial form and remains a diagnosis of exclusion. Both amylase and lipase are elevated but can return to normal levels temporarily. We present an interesting case of benign pancreatic hyperenzymemia. This case highlights the importance of identifying this condition to avoid unnecessary testing and reassuring the patient of its benign nature.
\end{abstract}

Categories: Internal Medicine, Medical Education, Gastroenterology Keywords: gullo's syndrome, hyperenzymemia, pancreas

\section{Introduction}

Pancreatic diseases are usually associated with an increase in the levels of the serum pancreatic enzymes. But few other non-pancreatic diseases have also been reported to have elevated levels of pancreatic enzymes, for example hypertriglyceridemia, macroamylasemia, duodenal ulcer, bowel obstruction, liver disease, malignancy, acute cholecystitis, etc [1]. Gullo described a new syndrome in 1996 which was characterized by persistently elevated levels of pancreatic enzymes in absence of clinical or pathological evidence of pancreatic disease and hence now known as benign pancreatic hyperenzymemia or Gullo's syndrome [2].

\section{Case Presentation}

A 43-year-old female with a history of renal stones status post lithotripsy was admitted for abdominal pain, urinary frequency and high-grade fever with chills that were going on for five days. Vitals signs on initial presentation showed a temperature of $103.9^{\circ} \mathrm{F}$, pulse rate of 98 /minute, blood pressure of $102 / 52 \mathrm{~mm} \mathrm{Hg}$ and respiratory rate of 16/minute. Physical examination was remarkable for mild abdominal tenderness on

Received 03/10/2020

Review began 03/13/2020 Review ended 05/03/2020 Published 05/15/2020

\section{() Copyright 2020}

Mehta et al. This is an open access article distributed under the terms of the Creative Commons Attribution License CC-BY 4.0., which permits unrestricted use, distribution, and reproduction in any medium, provided the original author and source are credited.

Initial workup revealed hemoglobin of $13.1 \mathrm{~g} / \mathrm{dl}$, hematocrit $40.9 \%$, white blood cell count of $17.9 \mathrm{X} 10^{3} / \mathrm{uL}$, and platelet count of $250 \mathrm{X} 10^{3} / \mathrm{uL}$. Metabolic panel and hepatic function panel were completely unremarkable with normal creatinine and transaminases. Urinalysis showed many bacteria and $100+$ white blood cells and was positive for leukocyte esterase and nitrites. Serum lipase and amylase level had been checked on presentation due to abdominal pain and came back elevated at $1142 \mathrm{U} / \mathrm{L}$ (Normal: 40-700 U/L) and $1024 \mathrm{U} / \mathrm{L}$ (Normal: 30-600 U/L) respectively. Lipase and amylase levels were monitored on a daily basis for 8 days and showed persistent elevation (Table 1). Isoamylase was not ordered due to the unavailability of the test at the facility. Abdominal pain resolved the next day. 


\section{Cureus}

\begin{tabular}{|c|c|c|}
\hline Day of Admission & Serum Lipase (U/L) & Serum Amylase (U/L) \\
\hline Day 1 & 1142 & 1024 \\
\hline Day 2 & 1309 & 1123 \\
\hline Day 3 & 2812 & 2213 \\
\hline Day 4 & 2613 & 2478 \\
\hline Day 5 & 2308 & 1872 \\
\hline Day 6 & 1638 & 1549 \\
\hline Day 7 & 1287 & 1156 \\
\hline Day 8 & 944 & 688 \\
\hline
\end{tabular}

TABLE 1: Levels of serum lipase and amylase levels over a period of 8 days from the time of admission.

Due to elevated pancreatic enzymes in the absence of any ongoing symptoms, further work to rule out any pancreatic etiology was done. The patient then underwent an ultrasound of the abdomen, CT scan of the abdomen with contrast and MRI of the abdomen with contrast. All three imaging studies were negative for any pancreatitis or pancreatic lesions and also did not show any other gastric, hepatic, biliary or small bowel abnormalities (figure 1-3).

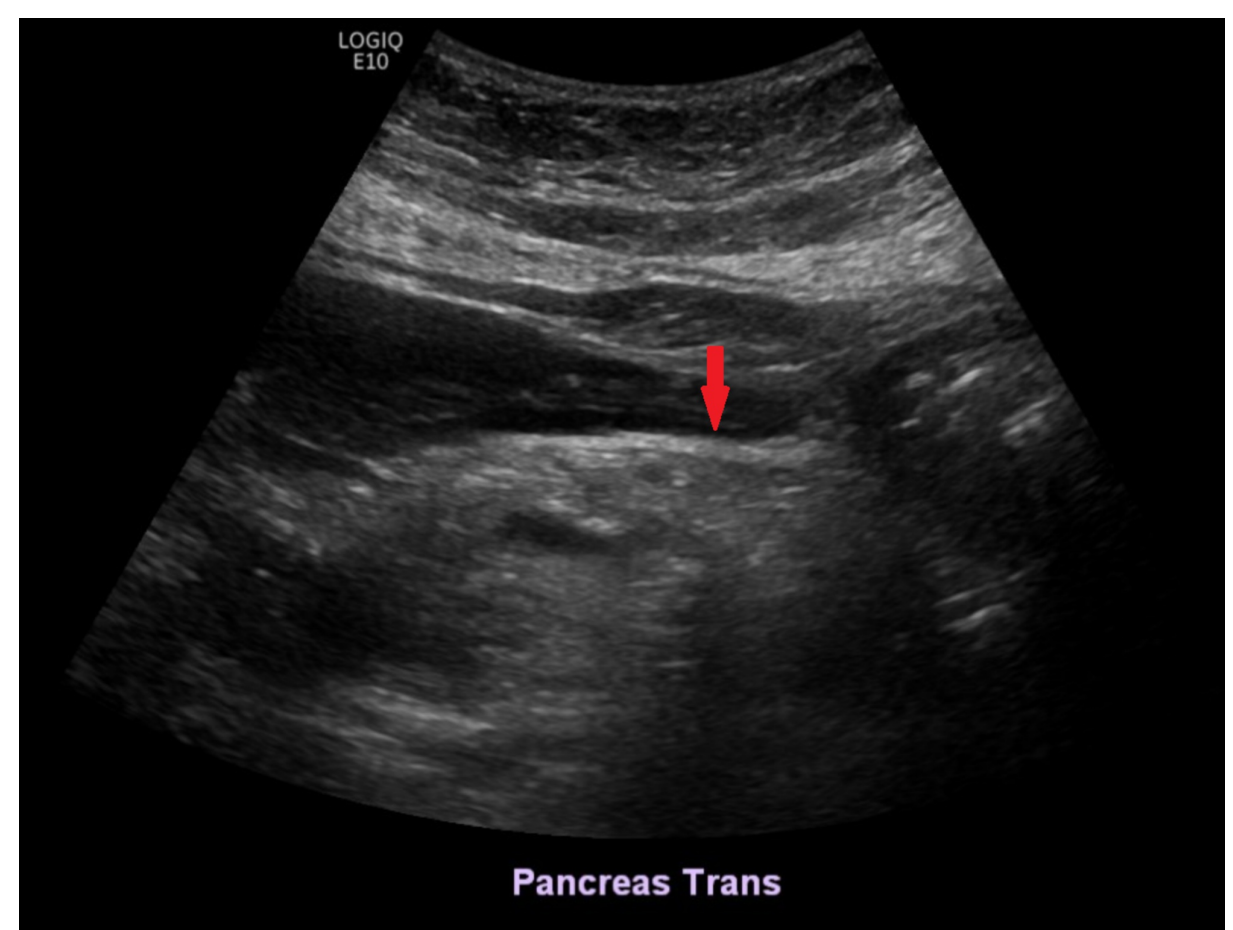

FIGURE 1: Ultrasound of the abdomen showing normal heterogeneous pancreas with hypo and hyperechogenicity of the parenchyma of the normal-sized pancreatic head and body, negative for parenchymal lesions or pancreatitis. The pancreatic tail was sub-optimally assessed due to overlying bowel gas. 


\section{Cureus}

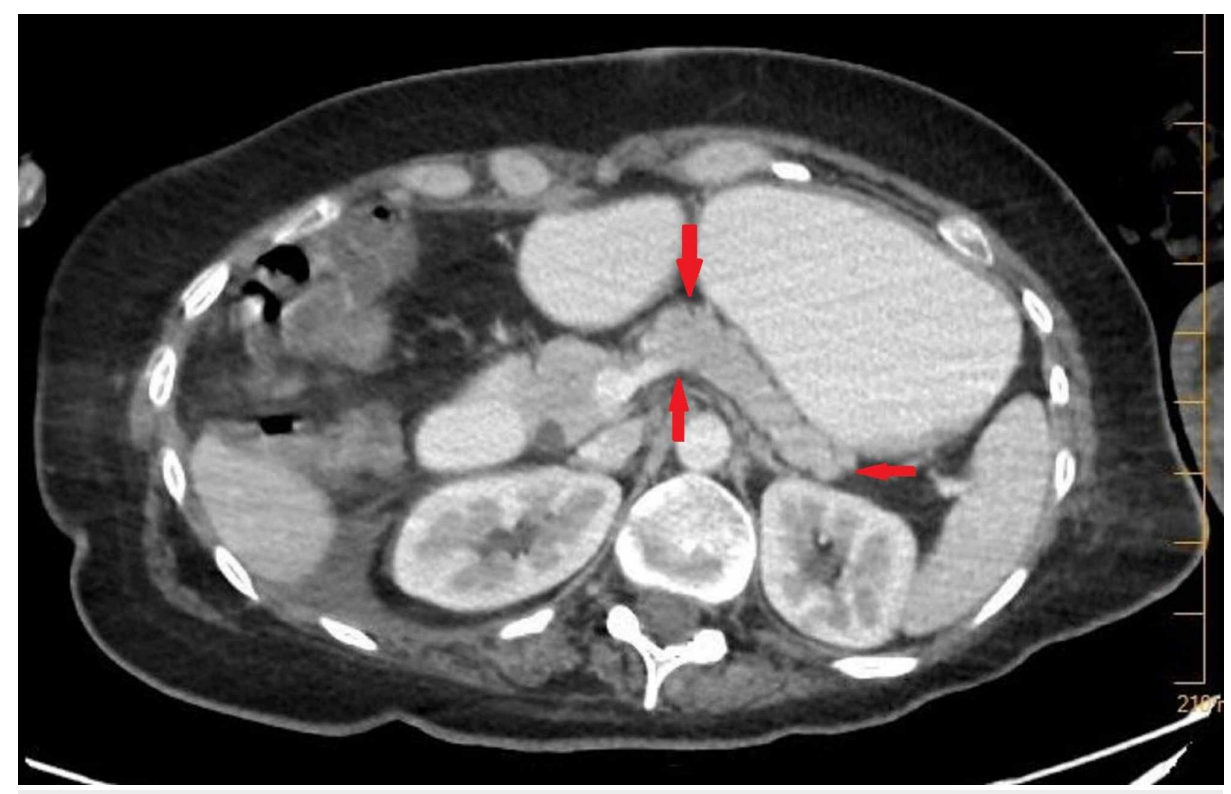

FIGURE 2: CT scan of the abdomen with contrast showing the normal pancreas without any pancreatitis or pancreatic lesions.

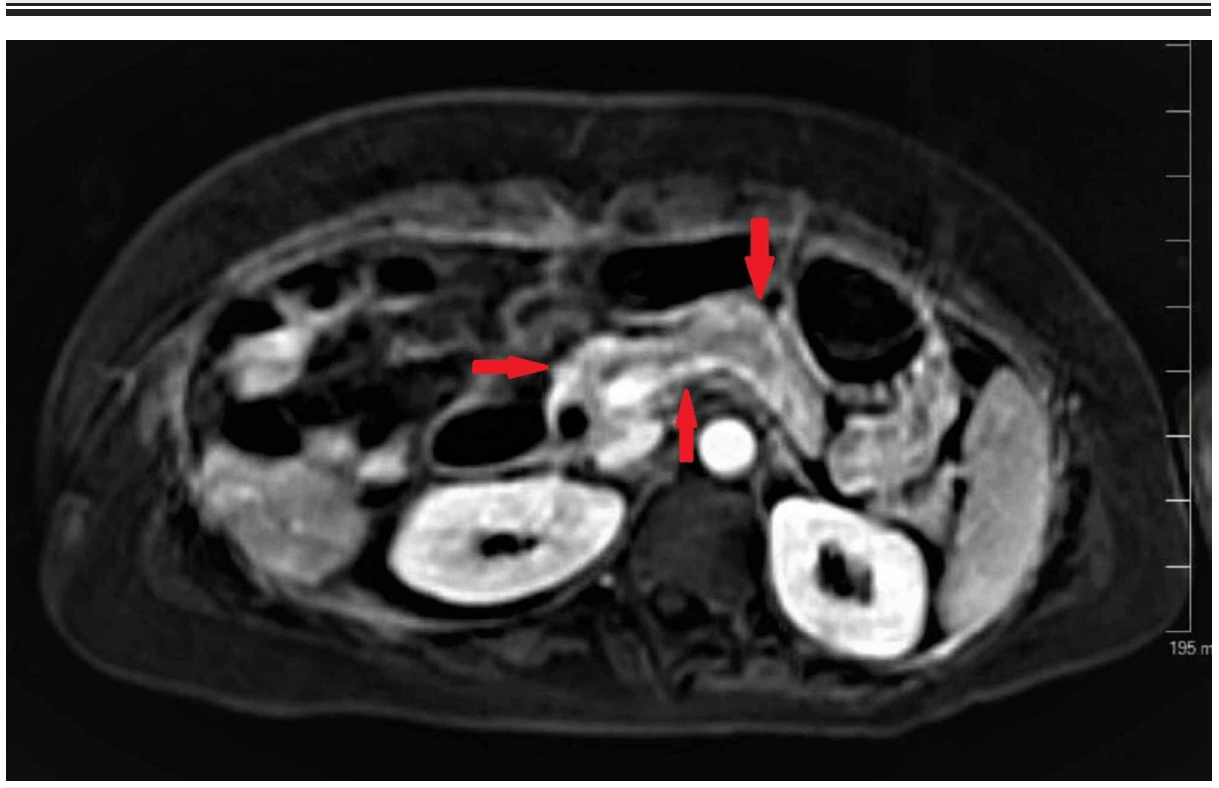

FIGURE 3: MRI of the abdomen with contrast showing the normal pancreas without any pancreatitis or pancreatic lesions.

Urine culture grew more than 100,00 colonies/ml E. coli. The patient was treated for sepsis secondary to UTI with appropriate antibiotics. Urinary frequency and high-grade fever with chills started improving and resolved 5 days after the patient was started on antibiotics. The patient was going to be discharged on the 5th day but her blood culture grew E.coli and she was kept for an additional two days. Repeat blood culture was done and remained negative. The patient was discharged on the 8th day of the admission.

She was followed up for eighteen months and remained completely asymptomatic without any recurrence of abdominal pain. Serum lipase and amylase levels were checked at twelve months and were found to be elevated at $832 \mathrm{U} / \mathrm{L}$ and $651 \mathrm{U} / \mathrm{L}$ respectively. At eighteen months, serum lipase and amylase levels were rechecked and were still found to be elevated at $768 \mathrm{U} / \mathrm{L}$ and $590 \mathrm{U} / \mathrm{L}$ respectively, leading to a diagnosis of Benign Pancreatic Hyperenzymemia. The patient was offered to undergo a repeat imaging study but she declined any further imaging.

\section{Discussion}


Pancreatic disorders are usually associated with elevated pancreatic enzymes. However, in benign pancreatic hyperenzymemia, persistent elevation of pancreatic enzymes including lipase, amylase, isoamylase without clinical or pathologic evidence of pancreatic disease with a normal pancreas on imaging studies is observed. Enzyme levels remain persistently elevated but can transiently return to normal levels and at least one year must pass after detection of hyperenzymemia before labeling it as Gullo's syndrome. This phenomenon was first described by the Italian gastroenterologist Dr. Lucio Gullo in 1996 where a healthy man with elevated serum pancreatic enzymes was admitted with a suspected pancreatic disease but all the imaging tests were normal. Initially, it was thought that persistent enzyme elevation could be due to chronic pancreatitis or pancreatic tumor, but no definite pathology was found. Dr. Gullo published several articles on it and hence it is known as Gullo's syndrome [3].

Benign pancreatic hyperenzymemia can occur sporadically or in familial form. The ratio of affected men and women is $1.5: 1$ but it can occur in children too. As it has been detected in more than one member of the family, the genetic basis for this disease has also been hypothesized. However, the exact mechanism remains unclear. CFTR (cystic fibrosis transmembrane regulator) mutation has been observed in patients with Gullo's syndrome. However, the frequency of this mutation is similar compared to the general population [4]. Some patients were evaluated by Dr. Gullo for PRSS1 mutation that is linked to hereditary pancreatitis and SPINK1 mutation that is linked to the pancreatitis of different etiologies. However, the PRSS1 mutation was not detected and the SPRINK1 mutation frequency was similar to the general population [5]. Relationship with celiac disease was studied as macroamylasemia is commonly associated with celiac disease where the chronic elevation of amylase levels is seen and lipase levels remain normal. However, in patients with Gullo's syndrome, pancreatic enzymes did not normalize after the gluten-free diet. Gullo's syndrome is also believed to be caused by a defect in the basolateral surface of the acinar cells causing an increase in the passage of enzymes into the blood or by the effect of secretin in the pancreatic duct of Wirsung. However, the study showed that change in the diameter of the duct was similar to the control group [6].

It is, however, an important point to remember that patients must be followed for a period of at least one year before labeling their pancreatic hyperenzymemia as benign because in 1-2\% of cases of pancreatic cancer, asymptomatic pancreatic hyperenzymemia can be an early witnessed laboratory abnormality [7].

\section{Conclusions}

Patients who have benign pancreatic hyperenzymemia or Gullo’s syndrome are not at high risk for developing pancreatitis. Since it is a benign syndrome, it is important to be aware of this condition to reassure patients to not worry and to avoid subjecting them to unnecessary testing and hospitalizations. However, it is also important to remember that patients must be followed for a period of at least one year before labelling their pancreatic hyperenzymemia as benign as in few cases of pancreatic cancer, asymptomatic pancreatic hyperenzymemia can be an early witnessed laboratory abnormality.

\section{Additional Information}

\section{Disclosures}

Human subjects: Consent was obtained by all participants in this study. Conflicts of interest: In compliance with the ICMJE uniform disclosure form, all authors declare the following: Payment/services info: All authors have declared that no financial support was received from any organization for the submitted work. Financial relationships: All authors have declared that they have no financial relationships at present or within the previous three years with any organizations that might have an interest in the submitted work. Other relationships: All authors have declared that there are no other relationships or activities that could appear to have influenced the submitted work.

\section{References}

1. Ainahi A, Ziane A, Wakrim L, Barakat A: An unusual case of Gullo's syndrome concomitant with serious endometriosis disease in a postmenopausal woman. Case Rep Med. 2018, 2018:1-4. 10.1155/2018/6310245

2. Gullo L: Chronic nonpathological hyperamylasemia of pancreatic origin . Gastroenterology. 1996, 110:19058. 10.1053/gast.1996.v110.pm8964417

3. Iriarte DA, Monzón AR, Bujanda, L: Gullo's syndrome (benign pancreatic hyperenzymemia): report of the first two cases in Basque Country. J Case Reports and Studies. 2019, 7:1.

4. Valente R, Antonelli M, Piciucchi M, et al.: Celiac disease and CFTR mutations in patients with chronic asymptomatic pancreatic hyperenzymemia. Am J Gastroenterol. 2013, 108:618. 10.1038/ajg.2013.13

5. Gullo L, Laghi L, Migliori M, et al.: SPINK1 and PRSS1 mutations in benign pancreatic hyperenzymemia . Pancreas. 2008, 37:31-5. 10.1097/MPA.0b013e31816172b7

6. Gullo L, Ventrucci M, Barakat B, Migliori M, Tomassetti P, Pezzilli R: Effect of secretin on serum pancreatic enzymes and on the Wirsung duct in chronic nonpathological pancreatic hyperenzymemia. Pancreatology. 2003, 3:191-4. 10.1159/000070728

7. Gullo L: Benign pancreatic hyperenzymemia. Dig Liver Dis. 2007, 39:698-702. 10.1016/j.dld.2007.03.005 